\title{
Helium isotope systematics in the vicinity of the Azores triple junction: Constraints on the Azores geodynamics
}

\author{
Pedro Madureira ${ }^{\mathrm{a}, \mathrm{b}, *}$, Manuel Moreira ${ }^{\mathrm{c}}$, João Mata ${ }^{\mathrm{d}}$, João Carlos Nunes ${ }^{\mathrm{e}}$, Cécile Gautheron ${ }^{\mathrm{f}}$, Nuno Lourenço ${ }^{\mathrm{g}}$, \\ Rosário Carvalho ${ }^{\mathrm{d}}$, Manuel Pinto de Abreu ${ }^{\mathrm{h}}$
}

a Estrutura de Missão para a Extensão da Plataforma Continental, Rua Costa Pinto, 165, 2770-047 Paço d'Arcos, Portugal

b Universidade de vora, Centro de Geofsica de vora, Departamento de Geocincias, Rua Romão Ramalho, 59, 7000-671 vora, Portugal

c Equipe de Géochimie et Cosmochimie, Institut de Physique du Globe de Paris, Sorbonne Paris Cité, CNRS (UMR 7154), 1 rue Jussieu, 75238 Paris Cedex, France

d Universidade de Lisboa, Faculdade de Cincias, Departamento de Geologia (GeoFCUL), Centro de Geologia da Universidade de Lisboa (CeGUL), Edifcio C6, Campo Grande,

1749-016 Lisboa, Portugal

e Universidade dos Açores, Departamento de Geocincias, R. Mãe de Deus, Apartado 1422, 9501-801 Ponta Delgada, Açores, Portugal

${ }^{\mathrm{f}}$ UMR Interactions et Dynamique des Environnements de Surface-CNRS 8148, Université Paris Sud, 91405 Orsay, France

g Instituto Portugus do Mar e da Atmosfera, Rua C do Aeroporto, 1749-077 Lisboa, Portugal

h MAM, Terreiro do Paço, Lisboa, Portugal

\section{a r t i c l e i n f o}

\section{Article history:}

Received 17 August 2013

Received in revised form 2 February 2014

Accepted 17 February 2014

Available online 26 February 2014

Editor: David R. Hilton

\section{Keywords:}

He isotopes

Terceira Rift

Eurasia Nubia boundary

Azores triple junction

\begin{abstract}
a b s t r a t
We present new He isotopic data from subaerial and submarine samples collected along the Terceira Rift (Azores Plateau) in order to constrain the sources involved in the Azores magmatism in the unique geodynamic context of the Azores triple junction. Lower than MORB ${ }^{4} \mathrm{He} /{ }^{3} \mathrm{He}$ isotopic ratios were determined on olivines from the Terceira Island and the adjacent Serreta submarine ridge (down to $\approx 69,000 ; \approx 10.5 \mathrm{R} / \mathrm{Ra}$ ), which in addition to the Ne isotopes previously published in Madureira et al. (2005) [Primitive helium and neon isotopes in Terceira Island: Constraints on the origin of the Azores archipelago. Earth and Planetary Science Letters 233, 429 440], support the geochemical models that consider the involvement of the lower mantle in the Azores magmatism. The analysis of He data published for the Mid-Atlantic Ridge (MAR) points to the existence of chemically distinct mantle domains underneath Eurasia and Nubia lithospheric plates, which can result from an heterogeneous distribution of asthenosphere metasomatism during the initial stages of plume activity in the Azores region. At the Terceira Rift, lavas from Graciosa Island, as well as from the western end of São Miguel Island and D. João de Castro Bank, display ${ }^{4} \mathrm{He} /{ }^{3} \mathrm{He}$ ratios similar to those observed along the MAR segments located to the north of the Azores triple junction area. Conversely, samples from the south Hirondelle Basin and also Faial display a He isotopic signature similar to that of MORB erupted along MAR segments located to the south of the Azores Plateau. The Terceira Rift and the Azores triple junction area are thus characterized by the mingling of two different asthenospheric domains referred as Eurasia and Nubia type and by the presence of mantle plume derived material having primitive helium signature.
\end{abstract}

(C) 2014 Elsevier B.V. All rights reserved.

\section{Introduction}

Mid-oceanic ridges represent the largest volcanic feature on Earth, from which Mid-Ocean Ridge Basalts (MORB) erupt. Unlike Ocean Island Basalts (OIB), the composition of most MORB records a marked depletion in incompatible elements inherited from their mantle source (e.g. Hofmann, 2003; Workman and Hart, 2005). However, MORB can also display enriched signatures in areas characterized by anomalous depths, higher heat flow and magma production, strong negative

* Corresponding author: Estrutura de Missão para a Extensão da Plataforma Continental, Rua Costa Pinto, 165, 2770-047 Paço d Arcos, Portugal. Tel: +351 213004165.

E-mail addresses: pedrom@emepc-portugal.org (P. Madureira), moreira@ipgp.fr (M. Moreira),jmata@fc.ul.pt (J. Mata),jcnunes@uac.pt (J.C. Nunes),

cecile.gautheron@u-psud.fr (C. Gautheron), nuno.lourenco@ipma.pt (N. Lourenco), mdrcarvalho@fc.ul.pt (R. Carvalho), manuel.abreu@mam.gov.pt (M.P. de Abreu). mantle Bouguer anomaly and thicker oceanic crust (e.g. Klein and Langmuir, 1987; Niu and O'Hara, 2008). In the North Atlantic, anomalous depths of the Mid-Atlantic Ridge (MAR) are particularly evident in Iceland and along the Azores bathymetric anomaly $\left(\sim 30^{\circ} \mathrm{N}\right.$ and $\sim 50^{\circ} \mathrm{N}$; Schilling et al., 1983; Dosso et al., 1999). At the Azores area this has been interpreted as resulting from the higher magma production rates triggered by the injection of deeper mantle material supplied by a plume (e.g. Adam et al., 2013 and references therein) also feeding the OIB which erupted at the Azores islands (Schilling, 1975).

Helium has been successfully applied to discriminate between MORB and OIB reservoirs and is considered fundamental to constrain mantle's structure and convection models (Kurz et al., 1982; Moreira et al., 1995; Moreira and Allègre, 1998; Sarda et al., 2000; Graham, 2002; Kurz et al., 2005). Helium has two isotopes, ${ }^{3} \mathrm{He}$ and ${ }^{4} \mathrm{He}$. The latter is radiogenic, being produced mostly in the radioactive chains of 